\title{
Influence of sea ice phenology on the movement ecology of ringed seals across their latitudinal range
}

\author{
David J. Yurkowski ${ }^{1, *}$, Christina A. D. Semeniuk ${ }^{1}$, Lois A. Harwood ${ }^{2}$, \\ Aqqalu Rosing-Asvid ${ }^{3}$, Rune Dietz ${ }^{4}$, Tanya M. Brown ${ }^{5}$, Sydney Clackett ${ }^{1}$, \\ Alice Grgicak-Mannion ${ }^{1}$, Aaron T. Fisk ${ }^{1}$, Steven H. Ferguson ${ }^{6}$ \\ ${ }^{1}$ Great Lakes Institute for Environmental Research, University of Windsor, 401 Sunset Avenue, Windsor, Ontario N9B 3P4, \\ Canada \\ ${ }^{2}$ Department of Fisheries and Oceans, 301-5204 50th Avenue, Yellowknife, Northwest Territories X1A 1E2, Canada \\ ${ }^{3}$ Greenland Institute of Natural Resources, Kivioq 2, PO Box 570, 3900 Nuuk, Greenland \\ ${ }^{4}$ Department of Bioscience, Aarhus University, Arctic Research Centre, Frederiksborgvej 399, 4000 Roskilde, Denmark \\ ${ }^{5}$ Department of Geography, Memorial University of Newfoundland, 230 Elizabeth Ave., St. John's, Newfoundland A1B 3X9, \\ Canada \\ ${ }^{6}$ Freshwater Institute, Department of Fisheries and Oceans, 501 University Crescent, Winnipeg, Manitoba R3T 2N6, Canada
}

\begin{abstract}
Environmental variation influences resource distribution, thereby affecting animal movement and foraging decisions. Climate change is altering environmental processes worldwide, but particularly in the Arctic, where changes in the phenology of sea ice have been redistributing resources across space and time. How polar marine predators such as ringed seals Pusa hispida hispida, whose ecology is tightly tied to sea ice, respond to different sea ice dynamics across large spatial scales is generally unknown. Here, behavioural states (resident and traveling) were estimated using state-space models on adult $(n=45)$ and subadult $(n=85)$ ringed seal satellite telemetry tracks from 6 Arctic locations. Tagged ringed seals spanned a wide latitudinal $\left(56.54^{\circ}\right.$ to $75.58^{\circ} \mathrm{N}$ ) and sea ice phenological range from short (1 to $2 \mathrm{mo}$ ) to longer (6 mo) ice-free periods. We assessed the influences of age class and several intra- and inter-annual environmental variables on ringed seal movement ecology. Both adults and subadults spent most of the icefree season in a resident state (93 and $77 \%$, respectively). A latitudinal gradient was characterised, where longer ice-free seasons and less inter-annual variability in sea ice phenology at lower latitudes were related to ringed seals spending more time in a resident state than their conspecifics at higher latitudes (90 versus $58 \%$, respectively), where the ice-free season was shorter and sea ice phenology between years was less synchronous. Ringed seals are responding to latitudinal differences in sea ice phenology which affect prey distribution, suggesting plasticity in their foraging decisions and spatiotemporal differences in prey distribution across the rapidly changing Arctic.
\end{abstract}

KEY WORDS: Animal movement $\cdot$ Spatial ecology $\cdot$ Arctic $\cdot$ Foraging behaviour $\cdot$ Climate change $\cdot$ Marine mammal

\section{INTRODUCTION}

The mechanisms and patterns governing an animal's movement ecology are dependent on the individual's internal physiological state, motion capacity

${ }^{*}$ Corresponding author: dyurkowski1@gmail.com and navigational ability through cognitive and sensory mechanisms and environmental context, which altogether influence how animals perceive, move and behave in spatial and temporal dimensions (Nathan et al. 2008). The subsequent movement strategies

(C) The authors and Fisheries and Oceans Canada 2016. Open Access under Creative Commons by Attribution Licence. Use, distribution and reproduction are unrestricted. Authors and original publication must be credited.

Publisher: Inter-Research · www.int-res.com 
adopted by species are not universally uniform, as behavioural decisions additionally depend on a multitude of factors relating to life history traits, population density, resource availability and distribution, patch size and habitat characteristics (Bowler \& Benton 2005). These differential movement strategies affect ecosystem structure and function, as animal movements transport and obtain biomass, nutrients and energy within and between heterogeneous ecosystems (Hussey et al. 2015), which couple animal diversity and ecosystem functioning across the globe (Bauer \& Hoye 2014).

Marine resources are spaced heterogeneously by physical, chemical and bathymetric features across the marine environment, which then drive the spatiotemporal distribution of marine predators (Stephens \& Krebs 1986, Block et al. 2011). For animals inhabiting ecosystems characterised by extreme variation in environmental variables and primary productivity through space and time, such as the Arctic, mobile predators should capitalise on the seasonal pulse of increased food availability by foraging efficiently to build energy stores for future use (McMeans et al. 2015). The seasonal periodicity of insolation and the extreme seasonality in sea ice extent characterise the Arctic marine ecosystem, leading to peak primary production during the ice-free season (Carmack \& Wassmann 2006). However, these environmental and ecological dynamics vary depending on latitude where the majority of primary production occurs during a short period of the year, ranging from 1 to 2 mo at high latitudes to approximately 6 mo at low latitudes. Arctic marine mammals are well adapted to these seasonal extremes in productivity by replenishing blubber stores during the ice-free season, which is a fundamental specialisation to their environment (Ryg \& Øritsland 1991, Moore \& Huntington 2008).

Ringed seals Pusa hispida hispida are an abundant near-top trophic level carnivore that have a circumpolar distribution and whose life history has been strongly shaped by sea ice dynamics (McLaren 1958, Smith \& Hammill 1981). Ringed seals primarily consume schooling pelagic forage fish such as Arctic cod Boreogadus saida, sandlance Ammodytes sp. and capelin Mallotus villosus, with diet varying by age, space (e.g. Lowry et al. 1980, Labansen et al. 2007, Yurkowski et al. 2016a) and season (e.g. Siegstad et al. 1998). Ringed seals forage more intensively during the resource-productive ice-free season, use a diversity of habitats from over the continental shelf to deep ocean basins (Freitas et al. 2008, Hamilton et al. 2015, Oksanen et al. 2015), and have been observed to transit thousands of kilometres (Harwood et al.
2012, Brown et al. 2014). Further, adults exhibit site fidelity and territoriality during the winter and spring, primarily in shore-fast ice for breeding, whereas subadults are likely competitively excluded to the resource-productive outer edges of shore-fast ice habitat (Crawford et al. 2012, Hamilton et al. 2016). As such, ringed seals provide an excellent model to examine the influence of age as well as variation in several environmental features including sea ice phenology on the movement ecology of a marine predator across a large spatial scale.

To analyse adult and subadult ringed seal movements and diving in the summer, fall and winter relative to the environment, we use a large and extensive long-term ARGOS satellite telemetry data set compiled across the North American Arctic and West Greenland. Specifically, we first examined whether ringed seals across the Arctic move, behave and dive similarly throughout the year despite geographic differences in the environment. Second, we investigated whether variability in ringed seal foraging behaviour changed in response to latitudinal variation in sea ice phenology within and between years. We hypothesised that ringed seals will respond to geographic differences in sea ice phenology and resource distribution by spending less time resident and more time traveling between foraging patches in areas with a shorter ice-free season and a patchier food distribution (i.e. higher latitudes) to maximise net energy gain. Third, we tested whether ringed seal foraging behaviour differed between adults and subadults across the Arctic, indicating ontogenetic variation in foraging strategies. We hypothesised that larger, older ringed seals will remain more resident than their smaller, younger conspecifics during the ice-free period, thus competitively excluding them from presumed higher-quality resource patches.

\section{MATERIALS AND METHODS}

\section{Study animals}

A total of 130 ringed seals were captured and deployed with satellite telemetry transmitters (see Harwood et al. 2012 and Luque et al. 2014 for specific details on capture, measuring and tagging procedures) at 6 locations across the North American Arctic and West Greenland. Capture locations were (1) Melville Bay, Northwest Greenland; (2) Resolute, Nunavut, Canada; (3) Cape Parry and Ulukhaktok, Northwest Territories, Canada, both encompassing the Amundsen Gulf; (4) Igloolik, Nunavut, Canada; 


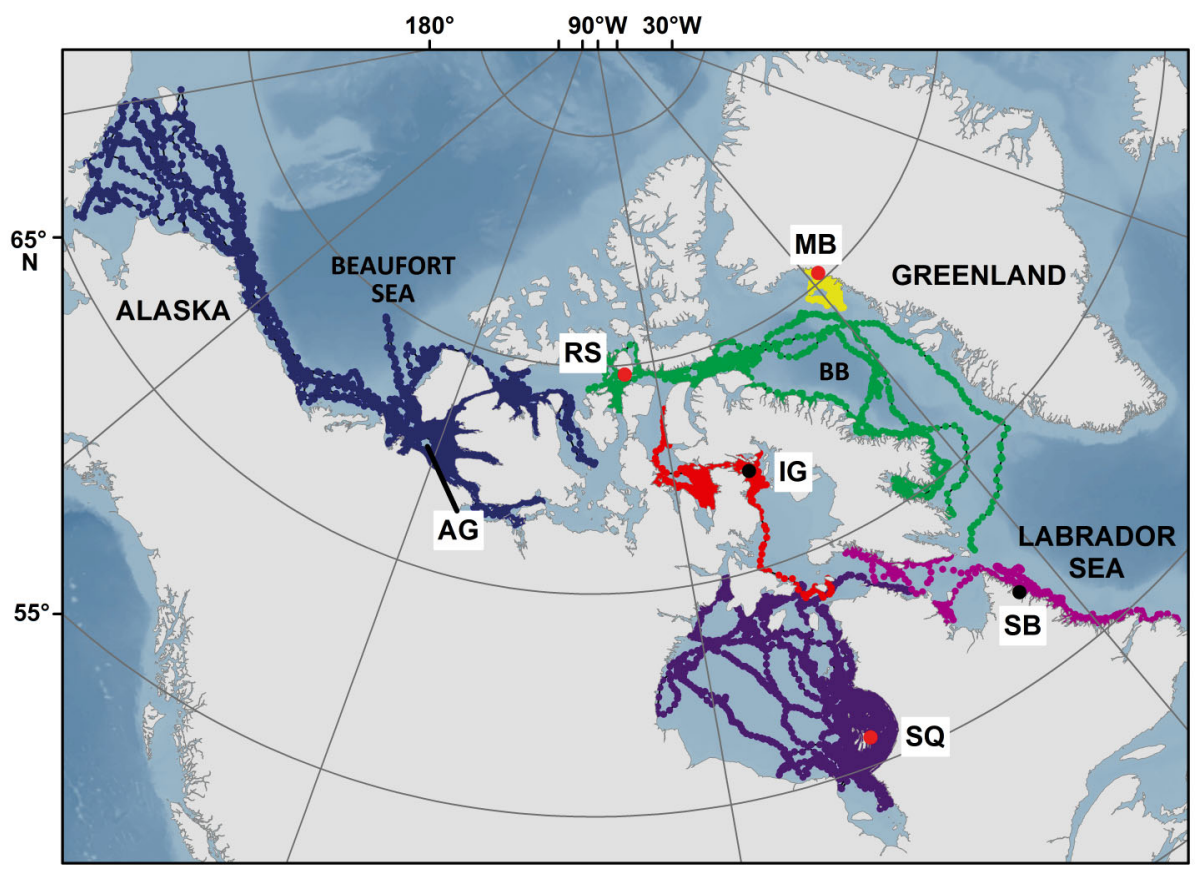

Fig. 1. Ringed seal movements across the Arctic with bathymetry highlighting communities of Melville Bay (MB, yellow tracks), Resolute (RS, green tracks), Amundsen Gulf (AG, blue tracks), Igloolik (IG, red tracks), Sanikiluaq (SQ, purple tracks) and Saglek Bay (SB, pink tracks), where ringed seals were equipped with satellite telemetry transmitters. BB: Baffin Bay

(5) Sanikiluaq, Nunavut, Canada; and (6) Saglek Bay, Labrador, Canada, and captures were conducted in the summer and fall (ranging from June to October) from 1999 to 2012 (Fig. 1; Table 1). A minimum age estimate was obtained by counting light and dark annuli on the claws (McLaren 1958). Ringed seals $\leq 5 \mathrm{yr}$ of age were considered subadults based on the age of sexual maturity ( $\geq 6 \mathrm{yr}$ of age, McLaren 1958; see Table S1 in the Supplement at www.int-res.com/ articles/suppl/m562p237_supp.pdf for morphometric measurements and satellite telemetry information per individual). A binomial general linear model with age class as the dependent variable and standard length as the independent variable revealed that

Table 1. Summary of ringed seal satellite telemetry data (mean \pm SD) by age class from 1999 to 2013 across the North American Arctic and Greenland

\begin{tabular}{|c|c|c|c|c|c|c|}
\hline Location & $\mathrm{n}$ & Year & Age class & $\begin{array}{l}\text { Tag duration } \\
\text { (d) }\end{array}$ & $\begin{array}{l}\text { Movement rate } \\
\left(\mathrm{km} \mathrm{d}^{-1}\right)\end{array}$ & $\begin{array}{l}\text { Time spent } \\
\text { resident (\%) }\end{array}$ \\
\hline Melville Bay & $\begin{array}{l}7 \\
3\end{array}$ & $\begin{array}{l}2011 \\
2011\end{array}$ & $\begin{array}{l}\text { Adult } \\
\text { Subadult }\end{array}$ & $\begin{array}{l}169 \pm 98 \\
103 \pm 24\end{array}$ & $\begin{array}{l}10 \pm 5 \\
14 \pm 7\end{array}$ & $\begin{array}{c}100 \pm 0 \\
98 \pm 2\end{array}$ \\
\hline Resolute & $\begin{array}{l}2 \\
5\end{array}$ & $\begin{array}{c}2013 \\
2012-2013\end{array}$ & $\begin{array}{l}\text { Adult } \\
\text { Subadult }\end{array}$ & $\begin{array}{c}146 \pm 137 \\
90 \pm 88\end{array}$ & $\begin{array}{l}25 \pm 14 \\
29 \pm 16\end{array}$ & $\begin{array}{l}63 \pm 43 \\
50 \pm 27\end{array}$ \\
\hline Amundsen Gulf & $\begin{array}{l}13 \\
10\end{array}$ & $\begin{array}{l}1999-2010 \\
1999-2010\end{array}$ & $\begin{array}{l}\text { Adult } \\
\text { Subadult }\end{array}$ & $\begin{array}{c}130 \pm 24 \\
91 \pm 48\end{array}$ & $\begin{array}{l}33 \pm 12 \\
46 \pm 15\end{array}$ & $\begin{array}{l}66 \pm 25 \\
24 \pm 22\end{array}$ \\
\hline Igloolik & $\begin{array}{l}1 \\
5\end{array}$ & $\begin{array}{l}2009 \\
2009\end{array}$ & $\begin{array}{l}\text { Adult } \\
\text { Subadult }\end{array}$ & $\begin{array}{c}89 \\
175 \pm 117\end{array}$ & $\begin{array}{c}24 \\
19 \pm 6\end{array}$ & $\begin{array}{c}69 \\
76 \pm 14\end{array}$ \\
\hline Sanikiluaq & $\begin{array}{l}20 \\
51\end{array}$ & $\begin{array}{l}2006-2012 \\
2006-2012\end{array}$ & $\begin{array}{l}\text { Adult } \\
\text { Subadult }\end{array}$ & $\begin{array}{l}145 \pm 79 \\
128 \pm 53\end{array}$ & $\begin{array}{l}19 \pm 9 \\
22 \pm 8\end{array}$ & $\begin{array}{l}85 \pm 22 \\
72 \pm 23\end{array}$ \\
\hline Saglek Bay & $\begin{array}{c}2 \\
11\end{array}$ & $\begin{array}{l}2008-2011 \\
2008-2011\end{array}$ & $\begin{array}{l}\text { Adult } \\
\text { Subadult }\end{array}$ & $\begin{array}{l}158 \pm 16 \\
135 \pm 74\end{array}$ & $\begin{array}{l}20 \pm 10 \\
22 \pm 10\end{array}$ & $\begin{array}{c}94 \pm 9 \\
88 \pm 12\end{array}$ \\
\hline Total & $\begin{array}{c}45 \\
85 \\
130\end{array}$ & & $\begin{array}{l}\text { Adult } \\
\text { Subadult } \\
\text { All }\end{array}$ & $\begin{array}{l}139 \pm 69 \\
123 \pm 63 \\
129 \pm 65\end{array}$ & $\begin{array}{l}22 \pm 12 \\
25 \pm 13 \\
24 \pm 13\end{array}$ & $\begin{array}{l}81 \pm 24 \\
68 \pm 29 \\
72 \pm 28\end{array}$ \\
\hline
\end{tabular}


adults were also significantly larger than subadults (slope $=0.11, \mathrm{p}<0.001, \mathrm{R}^{2}=0.46$ ).

\section{Study locations}

The general bathymetry varies between study locations, with relatively shallower topography near Melville Bay, Igloolik, Sanikiluaq and Saglek Bay than near Resolute and the Amundsen Gulf. Melville Bay, Saglek Bay and the Amundsen Gulf are adjacent to the deeper waters of Baffin Bay, the Labrador Sea and the Beaufort Sea, respectively. Sea ice composition also varies between study locations, where Melville Bay, Igloolik and Sanikiluaq primarily consist of shorefast first-year ice in the winter. In West Greenland, the coasts and fjords consist of high biological productivity because of rapid melting of the Greenland Ice Sheet due to the transport of relatively warmer North Atlantic water from the West Greenland Current (Holland et al. 2008, Motyka et al. 2011). The direction of sea ice formation in part of the Northwest Passage, which encompasses Resolute, is eastward towards Baffin Bay and is mainly composed of land-fast ice with some multi-year ice. The Amundsen Gulf is primarily composed of land-fast ice but with a recurrent Cape Bathurst polynya consisting of active pack ice, where a wind-driven Beaufort Gyre moves ice westward (Rigor et al. 2002). Saglek Bay consists of first-year shore-fast ice with moving pack ice in the Labrador Sea.

\section{Satellite telemetry}

Telemetry data were obtained via ARGOS satellite telemetry transmitters including SPOT5 (location recorders), SLTDR-10 and 16 and SPLASH (location and time-depth recorders) manufactured by Wildlife Computers (WC) and CTD and 9000x satellite relay data loggers (location and time depth recorders) from the Sea Mammal Research Unit (SMRU), University of St. Andrews, UK (Table S1 in the Supplement). The duration of satellite telemetry transmitter attachment on ringed seals across all locations ranged from 11 to $291 \mathrm{~d}(129 \pm 65 \mathrm{~d}$, mean $\pm \mathrm{SD}$; Tables 1 \& S1). On average, tracks consisted of 1361 locations (range: 126 to 5508 ) with 10.5 locations $\mathrm{d}^{-1}$. Individual dives were binned at depths exceeding $4 \mathrm{~m}$ for transmitters, with time-depth recordings sampling every second for WC transmitters deployed on Melville Bay seals, every $10 \mathrm{~s}$ for all other WC transmitters, and every $4 \mathrm{~s}$ for SMRU transmitters (Table S2 in the Supplement).

\section{Movement behaviour analysis}

To reduce ARGOS location error and estimate behavioural states (resident or traveling) for ringed seals, we used a discrete-time correlated random walk in the form of hierarchical Bayesian 2-state switching state-space models (SSMs), which improves parameter and location estimation (see Jonsen et al. 2005 and Jonsen 2016 for specific details). Traveling behaviour consists of fast, directed movements, whereas resident behaviour is identified by slow, tortuous movements thought to occur when encountering patchily distributed prey to increase foraging effort in these profitable patches (Kareiva \& Odell 1987, Dragon et al. 2012). Because of this large dataset and computational limitations restricting the fit of 1 large hierarchical SSM, we grouped ringed seals by capture location, tagging year and age class and fit each hierarchical SSM separately. Despite grouping individuals by capture location, no a priori bias existed for all estimated behavioural states and movement parameters. No significant relationships between the posterior median estimates for $\theta_{1}, \theta_{2}, \gamma_{1}, \gamma_{2}, \alpha_{1}, \alpha_{2}, \sigma_{1}$ and $\sigma_{2}$ (see Jonsen et al. 2005 for parameter descriptions) and latitude occurred using linear regression $\left(F_{1,21}\right.$ range $=0.04$ to $1.99, \mathrm{R}^{2}$ range $=0$ to $0.09, \mathrm{p}=0.17$ to 0.85 ). Each SSM was implemented using the package bsam v0.44 (Jonsen et al. 2013) in R v3.1.3 by running Markov Chain Monte Carlo (MCMC) methods using Just Another Gibbs Sampler at a time step of $12 \mathrm{~h}$. Two MCMC chains were run for 30000 iterations with a 20000 sample burn-in and thinned every 10 samples. Temporal autocorrelation was assessed visually via trace and autocorrelation plots, and chain convergence was estimated by Gelman and Rubin's potential scale reduction factor, which was $<1.1$ for all parameters. The SSM estimates 2 behavioural states (traveling and resident) along a continuum, thereby providing a level of certainty of being in a resident state, ranging from 0 (traveling) to 1 (resident).

We compiled summary dive records at every $12 \mathrm{~h}$ period for each individual, which included average maximum dive depth (m) and duration (s), coefficient of variation (CV) of maximum dive depth $(\mathrm{m})$ and duration (s), number of dives and a dive index (average maximum dive depth/ bathymetry) ranging from 0 (pelagic dive near the surface) to 1 (benthic dive). See Table 2 for ranges of environmental and dive parameters at each location. 


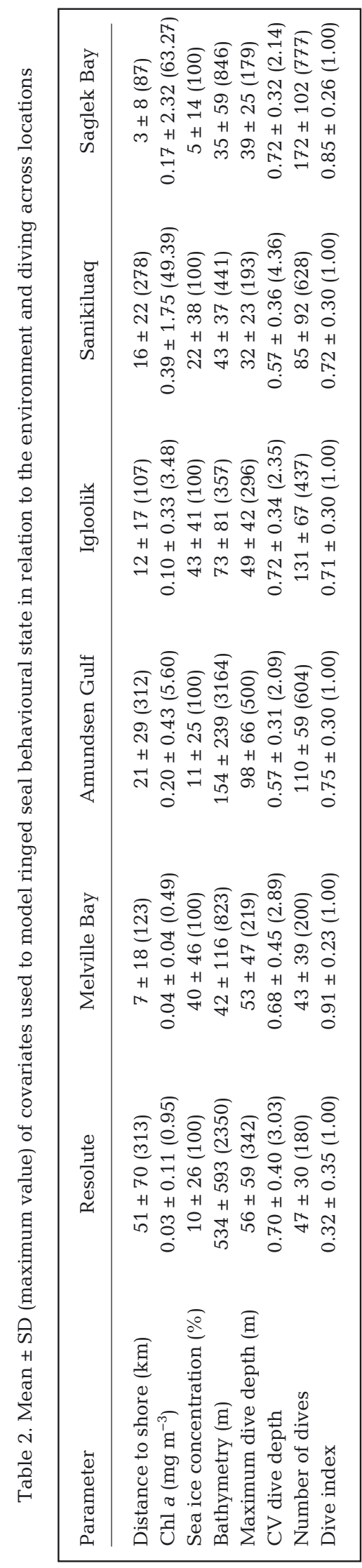

\section{Environmental variables}

A geographic information system (ArcGIS 10.1, Environmental Sciences Research Institute) was used to extract several environmental variables at each seal location estimate. Sea ice concentration (\%) data were obtained via Special Sensor Microwave/Imager (SSM/I) passive microwave data at a spatial resolution of $25 \mathrm{~km}$ in 8 d composite images (Cavalieri et al. 1996). Chl a ( $\left.\mathrm{mg} \mathrm{m}^{-3}\right)$ data were used as a proxy for resource abundance and collected via the MODIS-AQUA satellite at $4 \mathrm{~km}$ resolution in $8 \mathrm{~d}$ composite images (NASA Ocean Biology; http:// oceancolor.gsfc.nasa.gov, accessed September 2014). Sea floor depth (m) was extracted from GEBCO at a resolution of $30^{\circ}$ arc-seconds. We also calculated the shortest distance $(\mathrm{km})$ between seal location estimates and shoreline. We obtained the monthly phase (negative or positive) of the Arctic Oscillation (AO), which is an index of sea pressure anomalies north of $20^{\circ} \mathrm{N}$ (Thompson \& Wallace 1998), from the NOAA Climate Prediction Center (www.cpc.ncep.noaa.gov, accessed September 2014). To determine resident behaviour variability relative to sea ice phenology within and between years among study location, we obtained weekly sea ice concentration estimates from 1999 to 2013 encompassing each study location using the Canadian Ice Service's IceGraph 2.0 Tool (http://iceweb1.cis.ec.gc. ca/IceGraph, accessed September 2014) including eastern Baffin Bay (Melville Bay), eastern Parry Channel (Resolute), the Amundsen Gulf and mouth (Ulukhaktok and Cape Parry), Foxe Basin (Igloolik), eastern Hudson Bay (Sanikiluaq) and the northern Labrador Sea (Saglek Bay). Following the methods of Stirling et al. (1999), we defined the ice-free and ice-covered periods at each study location when total sea ice concentration was $<50 \%$ in the summer and $\geq 50 \%$ in the late fall. Sea ice concentrations under $50 \%$ generally coincide with peak phytoplankton biomass and productivity (Rysgaard et al. 1999, Smith et al. 2000).

\section{Data analysis}

To investigate relationships between behavioural state and environmental and dive parameters as well as all possible 2-way interactions, we used generalised linear mixed models (GLMMs) with a binomial error structure and logit link (logistic regression) using the package lme4 v1.1-8 (Bates et al. 2015) in R v3.2.0 (R Core Team 2015). Fixed effects included age class, bathymetry, sea ice and chl $a$, phase of the AO, distance to shore, mean maximum dive depth, $\mathrm{CV}$ dive depth, average dive duration, $\mathrm{CV}$ dive duration, number of dives and dive index. An optimal random effect structure was determined at each location using likelihood ratio tests $\left(\chi^{2}\right)$, where the best random effect structure included a sample ID intercept with ordinal date as a random slope to allow behavioural plasticity for each individual across time. Tagging year was removed as a random intercept, as its inclusion did not significantly improve model fit.

Continuous predictor variables were screened for collinearity and removed when a Pearson's correlation coefficient was $\geq 0.6$ and a variance inflation factor (VIF) was >3.0. In all models, we removed average dive duration and $\mathrm{CV}$ dive duration due to high correlation $(>0.7)$ with average maximum dive depth and CV dive depth, respectively. Bathymetry was also removed due to its correlation (>0.6) with 
distance to shore. In addition, most 2-way interactions between covariates at all locations were removed due to high collinearity evaluated using VIFs. We followed the model selection approach detailed in Zuur et al. (2009) using a backwards-step selection approach beginning with the full model and eliminating the most non-significant covariate until all remaining covariates were significant. Model selection was guided by Akaike's information criterion for small sample sizes $\left(\mathrm{AIC}_{\mathrm{c}}\right)$, where the lowest relative $\mathrm{AIC}_{\mathrm{C}}\left(\Delta \mathrm{AIC}_{\mathrm{C}}\right)$ was used to select the most parsimonious model using MuMIn v1.15.1 (Bartón 2015) in R. When several models had substantial support $\left(\Delta \mathrm{AIC}_{\mathrm{C}}\right.$ values <2.0), model coefficients were averaged to provide more robust parameter estimation (Burnham \& Anderson 2002). To assess model fit, we calculated marginal $\mathrm{R}^{2}$ (proportion of variance explained by fixed effects) and conditional $\mathrm{R}^{2}$ (proportion of variance explained by fixed and random effects) using the R package MuMIn.

Time spent in a resident state was not influenced by deployment date (movement rates: slope $=-0.01 \pm$ $0.03, \mathrm{R}^{2}=0.01, \mathrm{p}=0.89$; time spent resident: slope $=$ $-0.01 \pm 0.03, R^{2}=0.01, p=0.72$ ). A strong locational difference in the probability of exhibiting resident behaviour occurred $\left(F_{5,19520}=363.6, p<0.001\right.$; Fig. 2$)$. This further substantiated our reasoning for analysing by location, as the GLMMs performed at each location separately could thus examine whether environmental and dive parameters similarly or differentially explained ringed seal behavioural patterns between resident and traveling across the Arctic. The GLMM analysis could not be run on Melville Bay ringed seals due to $99 \%$ of estimated behavioural states being resident.

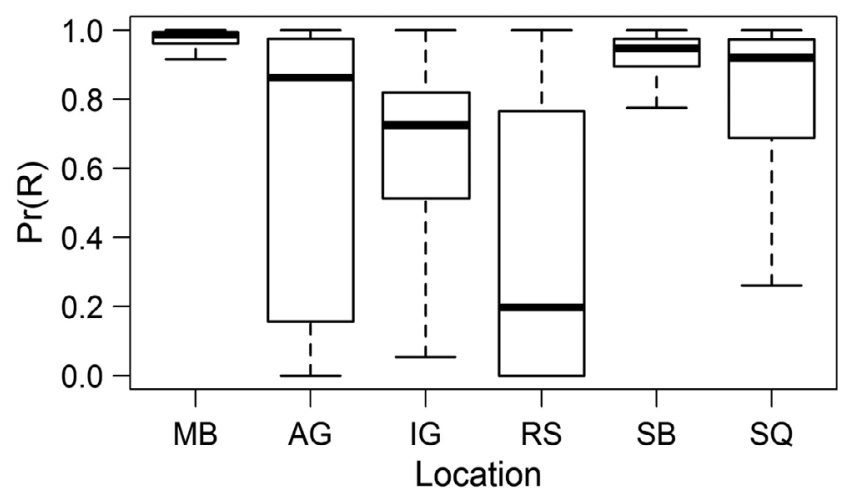

Fig. 2. Probability of being in a resident behavioural state, $\operatorname{Pr}(\mathrm{R})$, for ringed seals by location. Box-and-whisker plots: outside edges of the box $=$ first and third quartiles, middle line $=$ median, whiskers $=2$ SD. AG: Amundsen Gulf; IG: Igloolik; MB: Melville Bay; RS: Resolute; SB: Saglek Bay; SQ: Sanikiluaq
To examine foraging behaviour variability relative to environmental variation and age, we used logistic regression to test the effects of age class, latitude, CV and mean ice-free season duration from 1999 to 2013 on percentage of time ringed seals spent in a resident state during the ice-free period. The percentage of time in a resident state was calculated only for location estimates $<50 \%$ sea ice concentration to represent the resource-productive ice-free period and for individuals with tag durations $>30 \mathrm{~d}$. Prior to analysis, latitude and CV of ice-free season duration were removed due to their high correlation $(\geq 0.8)$ with mean of ice-free season duration; thus, the final model only included mean of ice-free season duration and age class relative to percentage of time in a resident state. For all significance tests, $\alpha$ was set to 0.05 .

\section{RESULTS}

We calculated a movement rate $\left(\mathrm{km} \mathrm{d}^{-1}\right)$ during the ice-free period per individual, which ranged from 2 to $75 \mathrm{~km} \mathrm{~d}^{-1}\left(21 \pm 12 \mathrm{~km} \mathrm{~d}^{-1}\right.$, mean $\left.\pm \mathrm{SD}\right)$ across all locations (Fig. 1, Table 1 and Table S1 in the Supplement at www.int-res.com/articles/suppl/m562p237_ supp.pdf). Generally, ringed seals tagged in Resolute and the Amundsen Gulf had higher movement rates than individuals at other locations (Tables 1 \& S1). Time spent in a resident state for adults and subadults, respectively, were highest in Melville Bay $(100 \pm 0$ and $98 \pm 2 \%$, mean \pm SD) and Saglek Bay $(94 \pm 9$ and $88 \pm 12 \%)$ and lowest in the Amundsen Gulf $(66 \pm 25$ and $24 \pm 22 \%)$ and Resolute $(63 \pm 43$ and $50 \pm 27 \%$; Fig. 3, Tables $1 \&$ S1).

\section{Relationship between behavioural state and environmental and dive variables}

The mixed effects models with the most support predicting behavioural state across all locations retained chl a concentration, mean maximum dive depth, CV dive depth and dive index. Age class and number of dives in Saglek Bay and distance to shore and sea ice concentration in Resolute were not retained (Table 3 and Table S3 in the Supplement for models ranked by $\mathrm{AIC}_{\mathrm{c}}$ ). Few interactions were retained at each location, with only those remaining between age class and sea ice concentration in the Amundsen Gulf, age class and AO phase in Resolute, age class and chl $a$ and age class and AO phase in Igloolik, and between age class and CV dive depth and number of dives in Sanikiluaq (Tables $3 \&$ S3). 

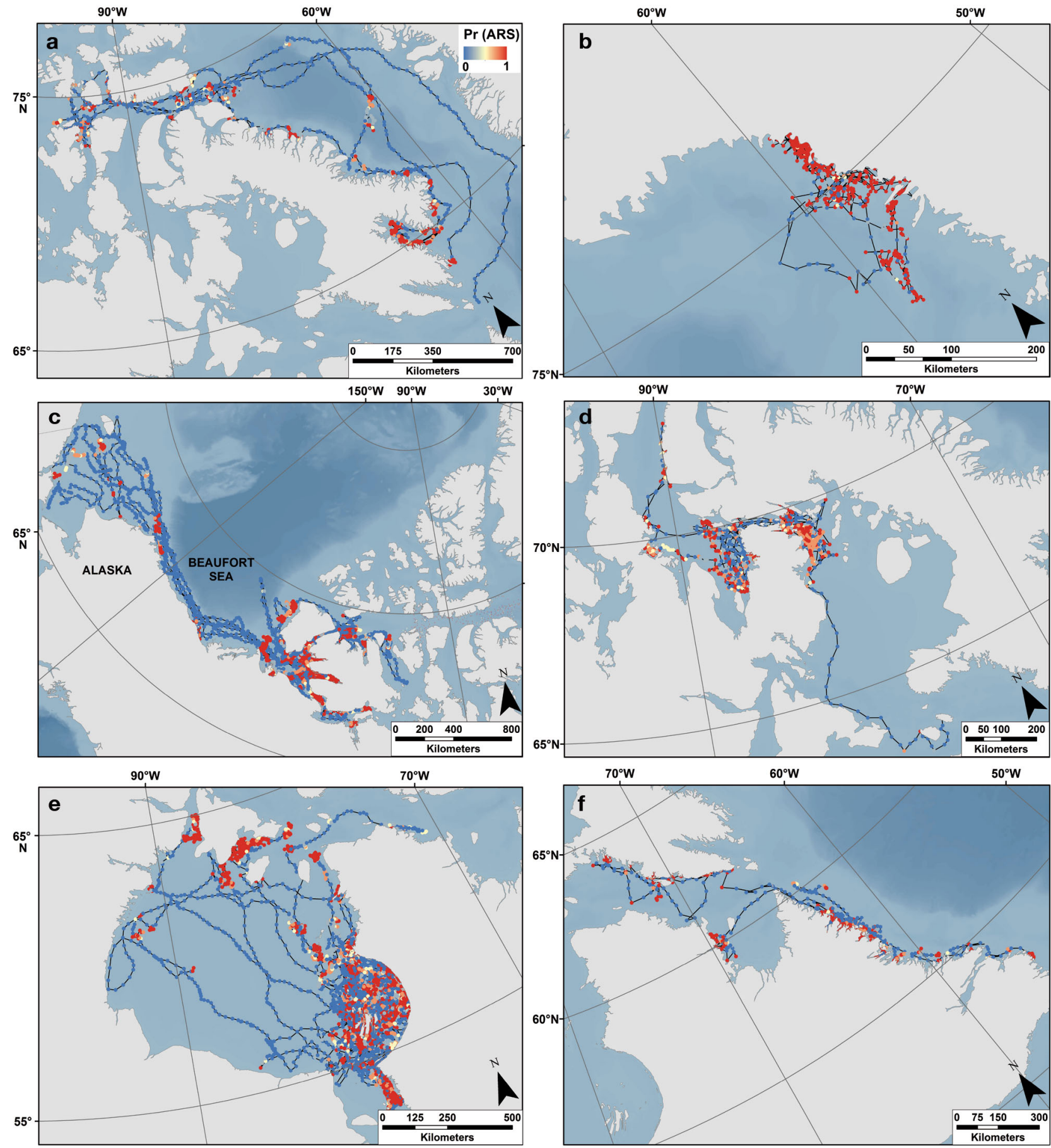

Fig. 3. Location estimates of ringed seals with an associated probability (0 to 1 ) of being in a resident behavioural state, Pr(R), in (a) Resolute, (b) Melville Bay, (c) Amundsen Gulf, (d) Igloolik, (e) Sanikiluaq and (f) Saglek Bay. Red locations indicate resident behaviour; blue locations infer traveling behaviour

Both fixed and random effects provided considerable explanatory power in predicting behavioural state across all locations, where the marginal $\mathrm{R}^{2} \mathrm{~s}$ for the best fit models ranged from 0.10 (Saglek Bay) to 0.22 (Resolute) and conditional $\mathrm{R}^{2}$ s ranged from 0.37 (Sanikiluaq) to 0.80 (Saglek Bay; Table S3).
Environmental covariates generally had similar relationships with behavioural state across all locations. Increased sea ice concentration was associated with resident behaviour in the Amundsen Gulf and Sanikiluaq, but this relationship reversed in Saglek Bay, where seals were traveling during higher sea 
Table 3. Mean \pm SE of parameter estimates from generalised linear mixed models predicting ringed seal behavioural state relative to environmental and dive covariates across sampling locations. Positive parameter estimates are associated with resident behaviour, and negative parameter estimates are associated with traveling behaviour. Variables with ' - ' were not included in the final model. Parameter values are in logit space, where bold parameter values indicate significance at the 0.05 level. ${ }^{*} \mathrm{p}<0.05,{ }^{* *} \mathrm{p}<0.01,{ }^{* * *} \mathrm{p}<0.001$

\begin{tabular}{|c|c|c|c|c|c|}
\hline Parameter & Resolute & Amundsen Gulf & Igloolik & Sanikiluaq & Saglek Bay \\
\hline Intercept & $0.780 \pm 0.518$ & $-1.007 \pm 0.548$ & $1.992 \pm 0.468^{* * *}$ & $1.722 \pm 0.137^{* * *}$ & $3.065 \pm 0.430^{* * *}$ \\
\hline Age class & $2.402 \pm 0.692^{* * *}$ & $1.606 \pm 0.543^{* *}$ & $2.158 \pm 0.647^{* * *}$ & $0.578 \pm 0.203^{* *}$ & - \\
\hline Distance to shore (m) & - & $-0.008 \pm 0.003^{*}$ & $0.004 \pm 0.006$ & $-0.008 \pm 0.001^{* * *}$ & $-0.088 \pm 0.013^{* * *}$ \\
\hline Chl a $\left(\mathrm{mg} \mathrm{m}^{-3}\right)$ & $-3.686 \pm 1.002^{* * *}$ & $-0.064 \pm 0.153$ & $-1.008 \pm 0.231^{* * *}$ & $-0.062 \pm 0.014^{* * *}$ & $-0.050 \pm 0.023^{*}$ \\
\hline Sea ice concentration (\%) & - & $2.599 \pm 0.501^{* * *}$ & $-0.083 \pm 0.273$ & $1.245 \pm 0.119^{* * *}$ & $-3.994 \pm 0.793^{* * *}$ \\
\hline Arctic Oscillation phase & $0.413 \pm 0.271$ & $-0.558 \pm 0.206^{* *}$ & $0.313 \pm 0.245$ & $0.341 \pm 0.077^{* * *}$ & $0.757 \pm 0.293^{* *}$ \\
\hline Mean maximum dive depth (m) & $-0.010 \pm 0.003^{* * *}$ & $0.002 \pm 0.001$ & $-0.019 \pm 0.003^{* * *}$ & $-0.023 \pm 0.001^{* * *}$ & $-0.018 \pm 0.004^{* * *}$ \\
\hline CV dive depth & $-1.265 \pm 0.314^{* * *}$ & $-0.485 \pm 0.247^{*}$ & $-1.262 \pm 0.285^{* * *}$ & $-0.603 \pm 0.085^{* * *}$ & $-0.911 \pm 0.285^{* *}$ \\
\hline Number of dives & $0.005 \pm 0.005$ & $0.002 \pm 0.001$ & $-0.001 \pm 0.001$ & $-0.001 \pm 0.001$ & - \\
\hline Dive index & $2.412 \pm 0.380^{* * *}$ & $1.090 \pm 0.283^{* * *}$ & $1.674 \pm 0.323^{* * *}$ & $1.219 \pm 0.110^{* * *}$ & $1.412 \pm 0.276^{* * *}$ \\
\hline Age class $\times$ sea ice concentration & - & $-4.110 \pm 0.695^{* * *}$ & - & - & - \\
\hline Age class $\times$ chl a & - & - & $-0.107 \pm 0.701$ & - & - \\
\hline Age class $\times$ CV dive depth & - & - & - & $-0.476 \pm 0.205^{*}$ & - \\
\hline Age class $\times$ number of dives & - & - & - & $0.003 \pm 0.001^{*}$ & - \\
\hline Age class $\times$ Arctic Oscillation & $-2.378 \pm 0.629^{* * *}$ & - & $0.376 \pm 0.477$ & - & - \\
\hline \multicolumn{6}{|l|}{ Random effects } \\
\hline ID estimated variance & $23.55 \pm 4.85$ & $46.33 \pm 6.81$ & $9.69 \pm 3.11$ & $0.08 \pm 0.29$ & $78.78 \pm 8.88$ \\
\hline Ordinal date estimated variance & $0.00058 \pm 0.024$ & $0.0007 \pm 0.0278$ & $0.00025 \pm 0.016$ & $0.00003 \pm 0.005$ & $0.001 \pm 0.032$ \\
\hline
\end{tabular}

ice concentrations (Table 3). In the Amundsen Gulf, subadults traveled more often in the ice-free period than adults who were mainly resident (Table 3). Seals resided closer to shore in the Amundsen Gulf, Sanikiluaq and Saglek Bay (Table 3). A positive AO phase was associated with resident behaviour in Resolute, Igloolik, Sanikiluaq and Saglek Bay but was reversed in the Amundsen Gulf, where seals were traveling during positive AO (Table 3). In Resolute, subadults exhibited resident behaviour in months of positive AO, whereas adults generally exhibited resident behaviour in months of positive and negative AO (Table 3). Higher chl a concentration inferred traveling behaviour in Resolute, Igloolik and Sanikiluaq (Table 3).

The diving covariates had similar relationships with behavioural state across locations. Ringed seals generally dove to deeper depths when traveling than when resident at most locations, except in the Amundsen Gulf (Table 3). Across all locations, a significant negative relationship occurred between $\mathrm{CV}$ dive depth and behavioural state (Table 3). In Sanikiluaq, adults dove more frequently and had a significantly lower CV depth when foraging than subadults. As well, dive index influenced behavioural state across all locations where seals utilised the sea floor when foraging (Table 3). Number of dives was not significant at any location (Table 3).

\section{Foraging behaviour variability relative to environmental variation and age class}

The duration of the ice-free season did not significantly change at any location from 1999 to 2013 (slope ranges $=-0.05$ [Saglek Bay] to 0.09 [Amundsen Gulf], p-value ranges $=0.10$ [Amundsen Gulf] to 0.91 [Sanikiluaq]) but was much longer in lower-latitude locations of Saglek Bay and Sanikiluaq (355 and $190 \mathrm{~d}$, respectively) than in Resolute and the Amundsen Gulf (102 and 115 d, respectively). Similarly, the $\mathrm{CV}$ in ice-free season duration between years at each location also varied with latitude, where it was highest in Resolute and the Amundsen Gulf (0.29 and 0.20 , respectively) compared to Saglek Bay and Sanikiluaq (0.06 and 0.1, respectively). A general latitudinal gradient occurred, where the proportion of time ringed seals spent in a resident state significantly increased with mean ice-free season duration (slope $=0.01 \%, p=0.01$; multiple $\mathrm{R}^{2}=0.18$; Fig. $4 \mathrm{a}$ ). Comparably, the proportion of time ringed seals spent in a resident state was higher in areas where sea ice phenology between years was more synchronous (Fig. 4b). Due to the high correlation between mean and CV of ice-free season duration (0.8), CV of icefree season duration was not included in the final model, but when modelled separately, time spent in a resident state significantly declined with $\mathrm{CV}$ of icefree season duration (slope $\pm \mathrm{SE}=-9.90 \pm 3.37, z=$ 
$-2.94, p=0.003)$. Ringed seals from Resolute and the Amundsen Gulf spent much less time resident (mean $=54$ and $46 \%$, respectively), except in Melville Bay (99\%), than conspecifics from lower latitudes (Igloolik: $75 \%$; Sanikiluaq: $75 \%$ and Saglek Bay: $89 \%$ ).

Adults spent significantly more time in a resident state than subadults throughout the year at most locations except in Saglek Bay (Table 3). During the ice-free period, however, the proportion of time spent in a resident state did not significantly differ between older, larger individuals and their younger, smaller conspecifics (slope $=0.78, p=0.10$; multiple $\mathrm{R}^{2}=0.18 ;$ Fig. 4c).

\section{DISCUSSION}

This is the first study to empirically demonstrate variability in movement rates and proportions of time spent in resident state across a marine predator's latitudinal range relative to sea ice phenology. Consistent with our hypothesis, we illustrate that at higher latitudes with a shorter ice-free season and more inter-annual variability in sea ice phenology, ringed seals spent less time resident and exhibited more traveling behaviour during the ice-free period than at lower latitudes. The exception was Melville Bay, where biological productivity is highest across the Arctic due to West Greenland glaciers and the relatively warmer West Greenland current. As such, ringed seals are responding to spatiotemporal differences in the distribution of prey resources driven by sea ice phenology, resulting in population-level differences in their movement behaviour. In addition, ringed seals across the Arctic exhibited similar diving behaviour when resident, suggesting similar foraging tactics at depth. In contrast to our second hypothesis, both age classes spent similar amounts of time in a resident state and adults did not competitively exclude younger seals from presumed foraging patches during the ice-free period.

\section{Resident behaviour relative to the environment}

The environment influences animal movement strategies in terms of cues, where information is integrated to inform behavioural decisions on which habitats to select (Clobert et al. 2009). In this study, the influence of sea ice concentration, distance to shore, phase of the AO and primary productivity on ringed seal foraging behaviour were not consistent between locations. In the Amundsen Gulf and Sani-
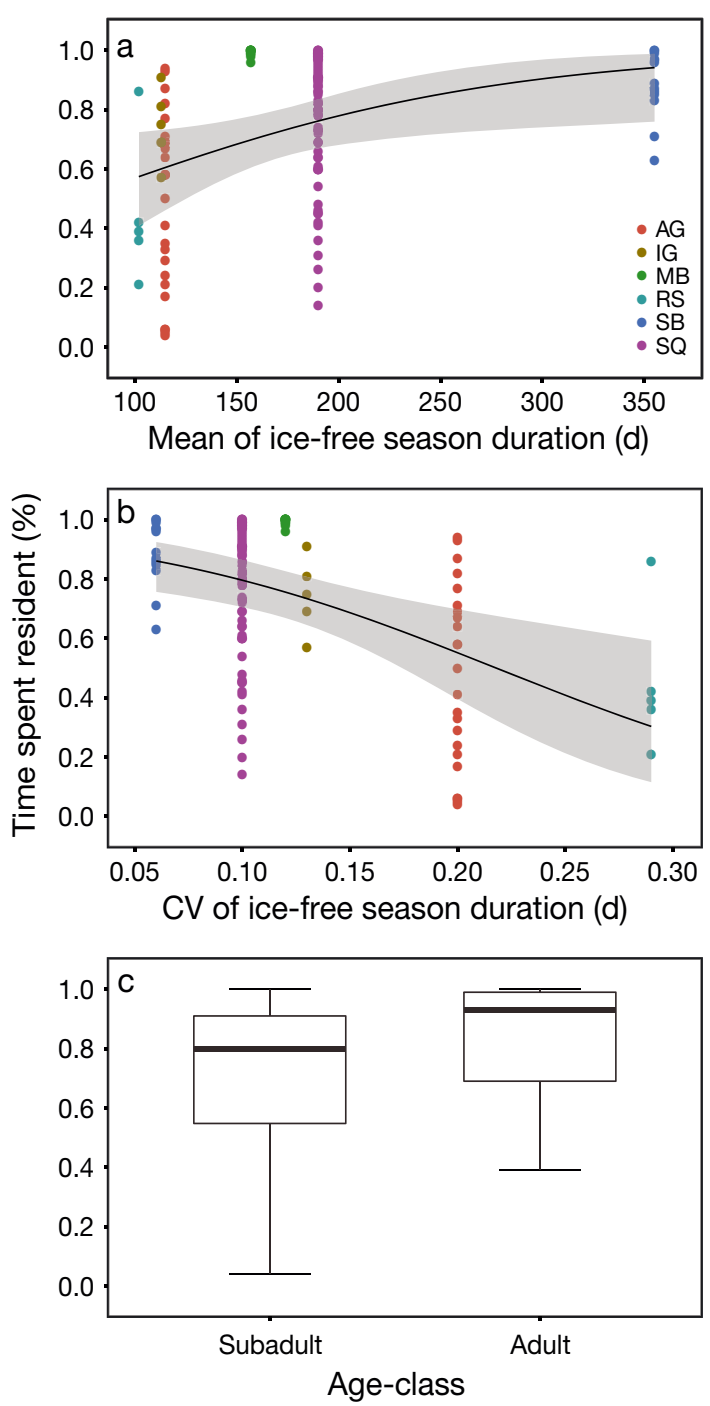

Fig. 4. Linear regressions of time spent resident for all ringed seal individuals by location relative to (a) mean and (b) CV of ice-free season duration and (c) age class. Gray shading in $(a, b)$ is the $95 \% \mathrm{CI}$. The legend in (a) corresponds to (b). Box-and-whisker plots: outside edges of the box $=$ first and third quartiles, middle line = median, whiskers $=2 \mathrm{SD}$. AG: Amundsen Gulf; IG: Igloolik; MB: Melville Bay; RS: Resolute; SB: Saglek Bay; SQ: Sanikiluaq

kiluaq during winter, ringed seals were resident in areas of stable shore-fast ice. Shore-fast ice with adequate snow cover allows ringed seals to minimise risk of predation by polar bears, who prefer to forage in areas of active sea ice further away from shore (Smith \& Hammill 1981, Pilfold et al. 2014). During winter at one of the most southern sampling locations (i.e. Saglek Bay), ringed seals traveled in areas of moving sea ice farther from shore, allowing more accessibility to different prey patches, similar to ringed seals in the Bering Sea, who are also at the southern limit of their distribution (Crawford et al. 2012). 
Large-scale climate variability indices such as the AO can be used as better predictors of ecological change than environmental factors at regional scales (Stenseth et al. 2002). In the Beaufort Sea, a positive AO phase weakens the wind-driven Beaufort Gyre, which in turn slows the westward sea ice transport (Rigor et al. 2002), possibly delaying the timing of phytoplankton blooms and resulting in ringed seals traveling more often in search of suitable prey patches. In contrast, resident behaviour occurred during positive $\mathrm{AO}$ phases for ringed seals at lower latitudes (Sanikiluaq and Saglek Bay), where the delay in the seasonal pulse of phytoplankton productivity could be offset by relatively higher prey species richness (Cheung et al. 2009), less spatially distributed prey or higher temporal predictability of prey. However, the mechanistic links between animal behaviour, resource productivity and large-scale climate variability indices are highly complex and require further investigation.

Chl a concentration, a proxy for primary productivity, was not a good indicator of ringed seal resident behaviour during the ice-free period. This could be attributed to the limitation of satellite-based data only assessing chl a concentration within the first few metres of the water column despite higher amounts of primary productivity occurring at deeper depths or due to a spatiotemporal lag effect between phytoplankton and zooplankton development influencing fish distribution (Grémillet et al. 2008).

\section{Resident behaviour and diving}

Swimming and diving are energetically costly; thus, air-breathing marine species are central-place foragers, where they must locate and capture prey in a 3-dimensional environment while returning back to the surface to meet their oxygen demands (Bestley et al. 2015). At all locations, the variation of dive depth for ringed seals was lower when resident than when traveling, suggesting the active pursuit and handling of prey at particular depths. Thus, locations where ringed seals were in a resident state may indicate areas of higher biological productivity and important marine habitat for marine megafauna, which are largely unknown across the Arctic.

\section{Resident behaviour relative to sea ice phenology}

Movement patterns reveal complex interactions between consumers and their environment by changing their behaviour and increasing their search radius to the spatial and temporal patterning of prey resources (Fauchald 1999). For example, Antarctic fur seal ArCtocephalus gazella foraging behaviour varied interannually by increasing their distance traveled and time spent searching for krill Euphausia superba patches between foraging bouts in response to the yearly variability in the spatial distribution of krill (Boyd 1996). We show that ringed seals inhabiting higher latitudes, with areas of more sea ice unpredictability between years and of shorter ice-free duration, spent considerably less time in a resident state and had higher movement rates than individuals at lower latitudes, where sea ice phenology was less variable inter-annually and had a longer open-water period. This is a probable response to latitudinal differences in the length of primary productivity ( 1 to 2 mo at most northern latitudes versus 6 to 7 mo at most southerly latitudes), which then propagates up the food web, affecting zooplankton and forage fish distribution, thereby influencing the movement behaviour of ringed seals. Similarly, polar bears Ursus maritimus, the main predator of ringed seals, also increase their home range in areas of higher sea ice variability as a response to low temporal predictability in prey availability and higher spatial heterogeneity in prey resource distribution (Ferguson et al. 1999).

Longer movements for different populations of a species have been linked to latitude, where individuals at higher latitudes and those that inhabit areas with greater environmental variation travel greater distances than their conspecifics at lower latitudes (Mueller \& Fagan 2008, Singh et al. 2012). Here, ringed seals across latitude are exhibiting 2 different population-level movement patterns, ranging from nomadic at higher latitudes to sedentary at lower latitudes. As almost a control group to illustrate this point, the high biological productivity of Northwest Greenland allowed ringed seals to solely exhibit resident behaviour and a sedentary range. Sedentary ranges of animals are comprised of resident strategies driven by low spatial dispersion and high temporal predictability of prey resources (Mueller \& Fagan 2008). At the other extreme, nomadism occurs when individuals must travel between numerous resource patches due to prey distributions being unpredictable in both space and time (Mueller \& Fagan 2008), which has been observed among terrestrial vertebrates (Mueller et al. 2011), avian predators (Clulow et al. 2011) and aquatic predators (Papastamatiou et al. 2009).

With strong spatial and temporal fluctuations in food availability across the Arctic, ringed seals, like 
most Arctic marine mammals, must capitalise on increased resource productivity through the proliferation of algal carbon sources by foraging heavily on zooplankton and fish to gain blubber stores for the upcoming less productive and prolonged winter period (Bluhm \& Gradinger 2008, McMeans et al. 2015). However, climate change is impacting these abiotic and biotic interactions across the Arctic with implications on overall trophodynamics (Post et al. 2013), especially with sub-Arctic forage fish such as capelin and sandlance becoming prevalent at lower latitudes and in the diets of marine megafauna (Gaston et al. 2003, Marcoux et al. 2012). As such, the diet of Arctic marine predators is more diverse and niche size is higher at lower latitudes due to increased prey diversity (Yurkowski et al. 2016b).

Since the 1990s, Arctic cod, whose high dispersal behaviour creates a patchy food distribution, are declining in abundance at low- and mid-Arctic latitudes due to high inter-specific competition with capelin (McNicholl et al. 2016), who, along with sandlance, have higher temporal predictability in their patch distribution (Fauchald \& Erikstad 2002, Haynes \& Robinson 2011). As a result, ringed seals inhabiting lower latitudes remained sedentary throughout the ice-free period, likely due to less-dispersed forage fish and more temporal predictability in their distribution caused by a longer ice-free period. With the continued reduction of sea ice extent, longer ice-free periods and northward expansion of sub-Arctic forage fish species being more punctuated at southerly latitudes (Wisz et al. 2015), plasticity in the movement ecology of ringed seals across the Arctic to changing abiotic and biotic factors is paramount to adjust to a rapidly changing climate. However, despite plasticity in the movement ecology of ringed seals, negative consequences of a changing climate on their demography and body condition have been observed at both lower and higher latitudes (Ferguson et al. 2005, Harwood et al. 2015).

\section{Resident behaviour relative to age}

Species compete for limiting resources which vary through space and time, leading to intraspecific competition for resources where individuals differ in their foraging strategies, foraging experience and competitive abilities to acquire more profitable prey resources (Amarasekare 2003). Here, when resource productivity was highest during the ice-free season, both older, larger and younger, smaller individuals spent most of their time in a resident state. Large aggregations of schooling fish prey occur in shallow waters near the coast, allowing high accessibility to prey resources, resulting in a spatial coexistence between age classes (Yurkowski et al. 2016a). However, spatial segregation between adults and subadults occurs during the less productive winter and spring breeding season where adult ringed seals establish territories underneath shore-fast ice that are restricted in size (Smith \& Hammill 1981), consistent with our results where adults were more likely to be in a resident state than subadults. Subadults inhabit active ice areas to overwinter which are relatively more biologically productive and lack the associated cost of defending underwater territories (Smith \& Hammill 1981, Kelly et al. 2010).

\section{CONCLUSION}

Across the latitudinal range of ringed seals, we have highlighted (1) the dissimilar influences of several environmental variables on their movement behaviour between geographic areas, (2) the similar influences of diving behaviour when in a resident state across locations, and (3) a latitudinal relationship where ringed seals inhabiting higher latitudes with shorter ice-free seasons spent less time in a resident state than their conspecifics at lower latitudes. Ringed seals are likely responding to large-scale spatiotemporal differences in prey distribution across the Arctic. These results have implications on regional and global management and conservation strategies for endemic Arctic marine mammals, many of whom are data poor with varying sensitivities to climate change (Laidre et al. 2008, 2015). Using large and extensive telemetry datasets of marine megafauna, researchers can shed new light on ecosystem trophodynamics and important marine habitats (Raymond et al. 2015, Hindell et al. 2016, Lascelles et al. 2016) to inform stakeholders with conservation planning efforts in response to a changing climate.

Acknowledgements. We thank the hunter and trapper associations across the Canadian Arctic and their hunters for assistance in the field, particularly Peter, Jeff and Uluriak Amarualik and Lucassie and Johnassie Ippak. We also thank Sebastian Luque for field assistance, Ian Jonsen for statistical advice and 3 anonymous reviewers whose comments considerably improved this manuscript. Animal handling was approved and conducted under the University of Windsor and University of Manitoba animal care committees and Fisheries and Oceans Canada licences to fish for scientific purposes (S-05/06 to 09/13-1006-NU). This study was supported by funding from Ministry of Mineral Resources, Government of Greenland, Polar Continental Shelf Project, 
NSERC-Ocean Tracking Network, NSERC-Discovery, Fisheries and Oceans Canada, Government of Nunavut and ArcticNet to A.T.F. and S.H.F. as well as the University of Windsor, Ontario Graduate Scholarships, an ESRI Canada GIS Scholarship and The W. Garfield Weston Foundation to D.J.Y.

\section{LITERATURE CITED}

Amarasekare P (2003) Competitive coexistence in spatially structured environments: a synthesis. Ecol Lett 6: 1109-1122

Bartón K (2015) MuMIn: multi-model inference. R package version 1.15.1 https://CRAN.R-project.org/package= MuMIn

Bates D, Maechler M, Bolker B, Walker S (2015) Fitting linear mixed-effects models using lme4. J Stat Softw 67: $1-48$

Bauer S, Hoye BJ (2014) Migratory animals couple biodiversity and ecosystem functioning worldwide. Science 344: 1242552

* Bestley S, Jonsen ID, Hindell MA, Harcourt RG, Gales NJ (2015) Taking animal tracking to new depths: synthesizing horizontal-vertical movement relationships for four marine predators. Ecology 96:417-427

Block BA, Jonsen ID, Jorgensen SJ, Winship AJ and others (2011) Tracking apex marine predator movements in a dynamic ocean. Nature 475:86-90

Bluhm BA, Gradinger R (2008) Regional variability in food availability for Arctic marine mammals. Ecol Appl 18: S77-S96

Bowler DE, Benton TG (2005) Causes and consequences of animal dispersal strategies: relating individual behaviour to spatial dynamics. Biol Rev Camb Philos Soc 80: 205-225

Boyd IL (1996) Temporal scales of foraging in a marine predator. Ecology 77:426-434

Brown TM, Luque S, Sjare B, Fisk AT, Helbing CC, Reimer KJ (2014) Satellite telemetry informs PCB source apportionment in a mobile, high trophic level marine mammal: the ringed seal (Pusa hispida). Environ Sci Technol 48: 13110-13119

Burnham KP, Anderson DR (2002) Model selection and multimodel inference: a practical information-theoretic approach. Springer, New York, NY

* Carmack E, Wassmann P (2006) Food webs and physicalbiological coupling on pan-Arctic shelves: unifying concepts and comprehensive perspectives. Prog Oceanogr 71:446-477

Cavalieri D, Parkinson C, Gloersen P, Zwally HJ (1996, updated yearly) Sea ice concentrations from Nimbus-7 SMMR and DMSP SSM/I-SSMIS passive microwave data, version 1. NASA DAAC at the National Snow and Ice Data Center, Boulder, CO

* Cheung WWL, Lam VWY, Sarmiento JL, Kearney K, Watson R, Pauly D (2009) Projecting global marine biodiversity impacts under climate change scenarios. Fish Fish 10: 235-251

Clobert J, Le Galliard JF, Cote J, Meylan S, Massot M (2009) Informed dispersal, heterogeneity in animal dispersal syndromes and the dynamics of spatially structured populations. Ecol Lett 12:197-209

Clulow S, Peters KL, Blundell AT, Kavanagh RP (2011) Resource predictability and foraging behaviour facilitate shifts between nomadism and residency in the eastern grass owl. J Zool (Lond) 284:294-299

Crawford JA, Frost KJ, Quakenbush LT, Whiting A (2012) Different habitat use strategies by subadult and adult ringed seals (Phoca hispida) in the Bering and Chukchi seas. Polar Biol 35:241-255

*Dagon AC, Bar-Hen A, Monestiez P, Guinet C (2012) Comparative analysis of methods for inferring successful foraging areas from Argos and GPS tracking data. Mar Ecol Prog Ser 452:253-267

Fauchald P (1999) Foraging in a hierarchical patch system. Am Nat 153:603-613

*Fauchald P, Erikstad KE (2002) Scale-dependent predatorprey interactions: the aggregative response of seabirds to prey under variable prey abundance and patchiness. Mar Ecol Prog Ser 231:279-291

FFerguson $\mathrm{SH}$, Taylor MK, Born EW, Rosing-Asvid A, Messier F (1999) Determinants of home range size for polar bears (Ursus maritimus). Ecol Lett 2:311-318

Ferguson SH, Stirling I, McLoughlin P (2005) Climate change and ringed seal (Phoca hispida) recruitment in western Hudson Bay. Mar Mamm Sci 21:121-135

Freitas C, Kovacs KM, Ims RA, Fedak MA, Lydersen C (2008) Ringed seal post-moulting movement tactics and habitat selection. Oecologia 155:193-204

Gaston AJ, Woo K, Hipfner JM (2003) Trends in forage fish populations in northern Hudson Bay since 1981, as determined from the diet of nestling thick-billed murres Uria lomvia. Arctic 56:227-233

Grémillet D, Lewis S, Drapeau L, van Der Lingen CD and others (2008) Spatial match-mismatch in the Benguela upwelling zone: Should we expect chlorophyll and seasurface temperature to predict marine predator distributions? J Appl Ecol 45:610-621

*Hamilton CD, Lydersen C, Ims RA, Kovacs KM (2015) Predictions replaced by facts: a keystone species' behavioural responses to declining arctic sea-ice. Biol Lett 11: 20150803

*Hamilton CD, Lydersen C, Ims RA, Kovacs KM (2016) Coastal habitat use by ringed seals Pusa hispida following a regional sea-ice collapse: importance of glacial refugia in a changing Arctic. Mar Ecol Prog Ser 545: 261-277

Harwood LA, Smith TG, Auld JC (2012) Fall migration of ringed seals (Phoca hispida) through the Beaufort and Chukchi Seas, 2001-02. Arctic 65:35-44

*Harwood LA, Smith TG, George JC, Sandstrom SJ, Walkusz W, Divoky GJ (2015) Change in the Beaufort Sea ecosystem: diverging trends in body condition and/or production in five marine vertebrate species. Prog Oceanogr 136:263-273

*Haynes TB, Robinson CLK (2011) Re-use of shallow sediment patches by Pacific sand lance (Ammodytes hexapterus) in Barkley Sound, British Columbia, Canada. Environ Biol Fishes 92:1-12

Hindell MA, McMahon CR, Bester MN, Boehme L and others (2016) Circumpolar habitat use in the southern elephant seal: implications for foraging success and population trajectories. Ecosphere 7:e01213

*Holland DM, Thomas RH, De Young B, Ribergaard MH, Lyberth B (2008) Acceleration of Jakobshavn Isbræ triggered by warm subsurface ocean waters. Nat Geosci 1: 659-664

*Hussey NE, Kessel ST, Aarestrup K, Cooke SJ and others (2015) Aquatic animal telemetry: a panoramic window into the underwater world. Science 348:1255642 
Jonsen I (2016) Joint estimation over multiple individuals improves behavioural state inference from animal movement data. Sci Rep 6:20625

Jonsen ID, Mills Flemming J, Myers RA (2005) Robust statespace modelling of animal movement data. Ecology 86: 2874-2880

Jonsen ID, Basson M, Bestley S, Bravington MV and others (2013) State-space models for biologgers: a methodological roadmap. Deep-Sea Res II 88-89:34-46

Kareiva P, Odell G (1987) Swarms of predators exhibit 'preytaxis' if individual predators use area restricted search. Am Nat 130:233-270

Kelly BP, Badajos OH, Kunnasranta M, Moran JR, MartinezBakker M, Wartzok D, Boveng P (2010) Seasonal homeranges and fidelity to breeding sites among ringed seals. Polar Biol 33:1095-1109

Labansen AL, Lydersen C, Haug T, Kovacs KM (2007) Spring diet of ringed seals (Phoca hispida) from northwestern Spitsbergen, Norway. ICES J Mar Sci 64:1246-1256

Laidre KL, Stirling I, Lowry LF, Wiig Ø, Heide-Jørgensen MP, Ferguson SH (2008) Quantifying the sensitivity of Arctic marine mammals to climate-induced habitat change. Ecol Appl 18:S97-S125

Laidre KL, Stern H, Kovacs KM, Lowry LF and others (2015) Arctic marine mammal population status, sea ice habitat loss, and conservation recommendations for the 21st century. Conserv Biol 29:724-737

Lascelles BG, Taylor PR, Miller MGR, Dias MP and others (2016) Applying global criteria to tracking data to define important areas for marine conservation. Divers Distrib 22:422-431

Lowry LF, Frost KJ, Burns JJ (1980) Variability in the diet of ringed seals, Phoca hispida, in Alaska. Can J Fish Aquat Sci 37:2254-2261

* Luque SP, Ferguson SH, Breed GA (2014) Spatial behaviour of a keystone Arctic marine predator and implications of climate warming in Hudson Bay. J Exp Mar Biol Ecol 461:504-515

Marcoux M, McMeans BC, Fisk AT, Ferguson SH (2012) Composition and temporal variation in the diet of beluga whales, derived from stable isotopes. Mar Ecol Prog Ser 471:283-291

McLaren IA (1958) The biology of the ringed seal (Phoca hispida) in the eastern Canadian Arctic. Bull Fish Res Board Can 118:1-97

McMeans BC, McCann KS, Humphries M, Rooney N, Fisk AT (2015) Food web structure in temporally-forced ecosystems. Trends Ecol Evol 30:662-672

McNicholl DG, Walkusz W, Davoren GK, Majewski AR, Reist JD (2016) Dietary characteristics of co-occurring polar cod (Boreogadus saida) and capelin (Mallotus villosus) in the Canadian Arctic, Darnley Bay. Polar Biol 39: 1099-1108

Moore SE, Huntington HP (2008) Arctic marine mammals and climate change: impacts and resilience. Ecol Appl 18:S157-S165

Motyka RJ, Truffer M, Fahnestock M, Mortensen J, Rysgaard S, Howat I (2011) Submarine melting of the 1985 Jakobshavn Isbræ floating tongue and the triggering of the current retreat. J Geophys Res 116:F01007

Mueller T, Fagan WF (2008) Search and navigation in dynamic environments-from individual behaviours to population distributions. Oikos 117:654-664

Mueller T, Olson KA, Dressler G, Leimgruber P and others (2011) How landscape dynamics link individual- to pop- ulation-level movement patterns: a multispecies comparison of ungulate data. Glob Ecol Biogeogr 20:683-694

* Nathan R, Getz WM, Revilla E, Holyoak M, Kadmon R, Saltz D, Smouse PE (2008) A movement ecology paradigm for unifying organismal movement research. Proc Natl Acad Sci USA 105:19052-19059

* Oksanen SM, Niemi M, Ahola MP, Kunnasranta M (2015) Identifying foraging habitats of Baltic ringed seals using movement data. Mov Ecol 3:33

*Papastamatiou YP, Lowe CG, Caselle JE, Friedlander AM (2009) Scale-dependent effects of habitat on movements and path structure of reef sharks at a predator-dominated atoll. Ecology 90:996-1008

Pilfold NW, Derocher AE, Richardson E (2014) Influence of intraspecific competition on the distribution of a wideranging, non-territorial carnivore. Glob Ecol Biogeogr 23:425-435

Post E, Bhatt US, Bitz CM, Brodie JF and others (2013) Ecological consequences of sea-ice decline. Science 341 : 519-524

R Core Team (2015) R: a language and environment for statistical computing. R Foundation for Statistical Computing, Vienna

Raymond B, Lea MA, Patterson T, Andrews-Goff V and others (2015) Important marine habitat off east Antarctica revealed by two decades of multi-species predator tracking. Ecography 38:121-129

* Rigor IG, Wallace JM, Colony RL (2002) Response of sea ice to Arctic oscillation. J Clim 15:2648-2663

* Ryg M, Øritsland NA (1991) Estimates of energy expenditure and energy consumption of ringed seals (Phoca hispida) throughout the year. Polar Res 10:595-602

Kysgaard S, Nielsen TG, Hansen BW (1999) Seasonal variation in nutrients, pelagic primary production and grazing in a high-Arctic coastal marine ecosystem, Young Sound, Northeast Greenland. Mar Ecol Prog Ser 179:13-25

* Siegstad H, Berner Neve P, Heide-Jørgensen MP, Härkönen $\mathrm{T}$ (1998) Diet of the ringed seal (Phoca hispida) in Greenland. NAMMCO Sci Publ 1:229-241

* Singh NJ, Börger L, Dettki H, Bunnefeld N, Ericsson G (2012) From migration to nomadism: movement variability in a northern ungulate across its latitudinal range. Ecol Appl 22:2007-2020

Smith TG, Hammill MO (1981) Ecology of the ringed seal, Phoca hispida, in its fast ice breeding habitat. Can J Zool 59:966-981

* Smith WO, Marra J, Hiscock MR, Barber RT (2000) The seasonal cycle of phytoplankton biomass and primary productivity in the Ross Sea, Antarctica. Deep-Sea Res II 47: 3119-3140

Stenseth NC, Mysterud A, Otterson G, Hurrell JW, Chan KS, Lima M (2002) Ecological effects of climate fluctuations. Science 297:1292-1296

Stephens DW, Krebs JR (1986) Foraging theory. Princeton University Press, Princeton, NJ

* Stirling I, Lunn NJ, Iacozza J (1999) Long-term trends in the population ecology of polar bears in western Hudson Bay in relation to climatic change. Arctic 52:294-306

* Thompson DWJ, Wallace JM (1998) The Arctic Oscillation signature in the wintertime geopotential height and temperature fields. Geophys Res Lett 25:1297-1300

Wisz MS, Broennimann O, Grønkjær P, Møller PR and others (2015) Arctic warming will promote Atlantic-Pacific fish interchange. Nat Clim Change 5:261-265

*Yurkowski DJ, Ferguson SH, Semeniuk CAD, Brown TM, 
Muir DCG, Fisk AT (2016a) Spatial and temporal variation of an ice-adapted predator's feeding ecology in a changing Arctic marine ecosystem. Oecologia 180: 631-644

Yurkowski DJ, Ferguson SH, Choy E, Loseto LL and others (2016b) Latitudinal variation in ecological opportunity

Editorial responsibility: Rory Wilson, Swansea, UK and intraspecific competition indicates differences in niche variability and diet specialization of arctic marine predators. Ecol Evol 6:1666-1678

Zuur AF, Ieno EN, Walker NJ, Saveliev AA, Smith GM (2009) Mixed effects models and extensions in ecology with R. Springer, New York, NY

Submitted: June 27, 2016; Accepted: October 14, 2016

Proofs received from author(s): December 15, 2016 